\title{
Self-efficacy and STEM: An Integrated Pedagogical Approach for Pre-service Elementary Teachers
}

\author{
Diana Fenton, Shannon Essler-Petty \\ College of St. Benedict, St. Joseph, MN and St. John's University, Collegeville, MN USA
}

\begin{abstract}
Teacher preparation for elementary education often separates pedagogical approaches by content. This study examines an integrative pedagogical approach in the areas of Science, Technology, Engineering, and Math (STEM) with elementary education majors. The preservice teachers were provided experiences to learn about pedagogical approaches for STEM integration and to design and implement interdisciplinary units with robotics in classroom settings as a part of a combined math and science pedagogy course. A modified version of the Science Teaching Efficacy Beliefs Instrument (STEBI-B) survey was used as a pre- and postassessment to determine if changes occurred in the preservice teacher's self-efficacy and outcome expectancy with elementary students as a result of this approach. Findings between pre- and post-assessments show increased means for both subscales: Personal STEM Teaching Efficacy (PSTE) and STEM Teaching Outcome Expectancy (STOE). Qualitative responses also indicate the beliefs and outcomes in STEM teaching were positively impacted. These findings indicate that a combined science-mathematics pedagogical approach that includes the development of units and teaching the units in authentic classrooms leads to more confidence in STEM teaching. The approach utilized in this study may serve as a model for other teacher preparation programs.
\end{abstract}

\section{Introduction}

Educational reform in the area of Science, Technology, Engineering, and Math (STEM) in K-12 schools is the focus of many initiatives in the United States. With the increasing number of STEM jobs available, an emphasis has been placed on STEM education in K-12 to provide a foundation of knowledge and skills to address this shortage. The President's Council of Advisors on Science and Technology (PCAST) has called for 100,000 newly prepared STEM teachers by the year 2020. The need exists to prepare effective STEM teachers [1], [2]. Recognizing the complexity of STEM education, integrated STEM education was conceptualized as the intentional blendings of science, technology, engineering, and mathematics to deepen elementary student understanding of each discipline [3]. For the purpose of this study, this blending of content within specific units and lessons will be considered interdisciplinary.

Enhancing the quality and quantity of K-12 STEM education requires providing professional development opportunities for in-service teachers. Positive shifts in perceptions and conceptions of STEM education and motivations for teaching STEM were reported after inservice teachers participated in professional development. The notable shift was associated with the collaborative process and structured planning time during professional development [4], [5]. Results of similar studies with secondary teachers indicated an emphasis on collaboration and teamwork to make integrated instruction more efficient and less difficult [6]. However, enhancing current teacher preparation programs with a STEM emphasis for pre-service teachers is also required [7]. Exposed to approaches that integrate STEM, preservice teachers were able to effectively develop connections and pedagogical approaches for STEM integration [8]. Therefore, it is necessary to provide opportunities for pre-service teachers to design and integrate interdisciplinary STEM units during teacher preparation to increase exposure to effective STEM pedagogical practices in elementary schools.

\section{Self-Efficacy}

Barriers exist with both in-service and pre-service teachers in the confidence and the basic knowledge for integration of effective STEM teaching. A person with high self-efficacy is confident about a specific task that may influence his or her behavior. Self-efficacy is often a predictor of STEM integration [9]. When Bandura's theory of social learning is applied to elementary STEM teaching, one can infer that if teachers have low science teaching efficacy, they are likely to avoid teaching STEM 
[10], [11], [12], [13]. Researchers have demonstrated that elementary teachers with low science efficacy tend to avoid science instruction, teach it sporadically, or give it inadequate time [14][15]. Lack of teacher comfort can also have a negative impact on the learning and perceptions of STEM in elementary students [16]. Due to the lack of confidence, many in-service and pre-service teachers lack role models in STEM because STEM lessons were not a part of classroom experiences when they were in school and they do not exist in many current classrooms today [17].

Pedagogical preparation and content knowledge are also linked to efficacy. Researchers suggest high-quality science coursework has the potential to shape pre-service teachers' science self-efficacy beliefs [18]. One would expect an effective teacher to have well-structured pedagogical and content knowledge and consequently, a higher sense of teaching efficacy. Elementary teachers often are less confident in the content areas in science and math and reluctant to teach it. Coburn and Loving [19] surveyed elementary teachers and found that although over three fourths (76\%) of respondents claimed competence to teach reading/language arts, fewer than one third (28\%) felt the same about science.

As a result, STEM education is weaker in elementary schools despite the long term impact on elementary students' career interests [20], [21], [22]. Dejarnette [23] identifies elementary grades as a key target to foster curiosity in STEM subject areas, allowing for continued interest and learning among elementary students. Therefore, increasing confidence in elementary teachers to teach STEM is important in developing tomorrow's workforce.

\subsection{Teacher Preparation}

Many schools and curriculums emphasize the importance of STEM, yet the preparation of elementary pre-service teachers does not always include required courses to prepare them to teach it. In many teacher preparation programs, teaching methods courses typically include science, math, social studies, and literacy with either a stand-alone technology course or technology embedded throughout the coursework. Pedagogical approaches to design and integrate interdisciplinary units or to integrate technology are challenging. In addition to method courses, content courses taken by elementary preservice teachers are limited to one or two courses in the content areas of science and math, giving pre-service teachers a limited background in content preparation.
In field placements at schools, pre-service teachers do not always witness interdisciplinary teaching or technology integration because in-service teachers are often limited to content they teach due to mandatory standardized tests the students will be taking. Challenges also exists that when pre-service teachers are placed in the field for practicum or their final student teaching experience, choice in the content is not often determined by the pre-service teachers, and development of interdisciplinary lessons or units are not emphasized.

In order to keep up with current trends, teacher preparation programs should be preparing teacher candidates to be able to adopt this changing context of STEM education and teach STEM through integrated approaches [24], [25]. Innovative approaches to increase STEM integration have been developed for some teacher preparation programs including course development with co-taught courses across different disciplines, for example, biology faculty teaching with education faculty. Positive results in confidence and content knowledge in the STEM disciplines were indicated, but this approach did not include a teaching experience [26]. Other program's efforts have been made to provide pre-service elementary teachers with content learning experiences that integrate STEM disciplines [27], [28]. In teacher preparation programs, participation in semester-long activities has been shown to equip pre-service teachers with creative methods of teaching K-12 engineering at the elementary level [29]. Teacher educators of these programs argued that this learning experience would help pre-service teachers learn STEM content and prepare them to teach STEM in an integrated manner. Long term impacts of teacher preparation programs have had mixed results despite their strong beliefs about STEM integration, pre-service teachers reported an increased feeling of difficulty in implementing STEM integration units after completion of a teacher preparation program [30].

\subsection{Technology and Robotics}

Integrating STEM in methods courses with preservice teachers can begin to build the skills necessary to teach it. Blending robotics within STEM lessons provides additional skills of problem-solving, critical thinking, collaboration, and technology integration which are all essential for STEM careers. Technology has been found as the most difficult aspect of STEM to ingrate [31]. Robotics in education can combine all STEM disciplines to motivate elementary students in the classroom because of the unique problem-solving and immediate feedback. Many studies have explored the use 
of robotics for engineering integration [32]. Robotics can be one of the most successful programs that take place in school curriculums to support elementary students' academic demands in STEM [33], [34], [35]. Robotics in after-school programs and clubs has become widely used; however, classroom integration initiatives have only recently begun due to the expanse selection and lower cost of the robotic devices [36], [37]. When considering using any technology or robotics, technology should not be an "add-on" but embedded within existing content. While most teachers believe that technology will benefit all students, many of today's educators fail to integrate technology into their curriculum or integrate it in a meaningful way. Teacher training on the effective use of robotics instruction is needed. Integrating technology into methods and content courses to foster technology skills connected to use in PK-12 instruction has been valued as a critical component in the development of teacher candidates [38], [39], [40]. The technology, pedagogy, and content knowledge framework (TPACK) is an established framework for infusing technology in teacher preparation programs. Workshops have been shown to increase the teacher's confidence in the knowledge of robotic programming and their efficacy in STEM teaching [41]. Integrating technology and robotics is difficult for in-service teachers. In a previous literature review, Kim et al. [42] found it difficult to find studies involving pre-service teachers' training to use educational robots to integrate STEM. They conducted some beginning work in this area and found improved attitudes toward STEM and engagements using robotic, yet the pre-service teachers were not required to design a lesson that would specifically focus on STEM content.

\section{Purpose of the Study}

The purpose of this study was to address the need to prepare pre-service teachers with the pedagogical and content knowledge to teach interdisciplinary STEM. To address this well-established need, a combined pedagogy course and practicum experience that included the integration of robotic devices based on the grade level was created. This combined structure was required for all elementary education majors. Pre-service teachers were dual enrolled in the math and science pedagogy courses, but the instruction was delivered in a co-taught model. This model did not impact credit load or add additional courses to the current elementary education major. Assignments and content topics throughout the course were delivered not to focus on one content, but to provide the connections between the content of science, math, engineering, and technology. During the course, the pre- service teachers developed an interdisciplinary math and science unit that integrated computer science and robotics (technology) using state content area standards. The robotic tool used varied by grade. This unit was then taught by the pre-service students in an elementary classroom in a two-week continuous experience. Preservice teachers taught in teams of two or three to allow for a more collaborative method of planning and teaching, with each taking the lead role in teaching multiple lessons throughout the two weeks. Multiple classrooms at one grade level allowed for even greater collaboration between the pre-service teachers in the course. The instructors were on-site each day for the preservice teachers to obtain support by providing feedback on lesson design and integration. The research question guiding this study is: How do pre-service elementary teachers' perceptions of their effectiveness for teaching STEM change during a combined pedagogy course?

\section{Methods}

\subsection{Participants}

A total of 46 undergraduate pre-service teacher candidates were invited to participate in the study over two semesters of one academic year. All 46 pre-service teacher candidates enrolled in the two courses voluntarily participated. The pre-service teachers were dual enrolled in the math and science pedagogy courses, but the instructors co-taught the course throughout the 16 week semester. This allowed for the pre-service teachers and instructors to meet daily and to teach two consecutive weeks in a practicum classroom setting. The pre-service teachers participated in STEM activities during the course similar to ones they would later teach. As the preservice teachers participated in the activities, they also explored research on STEM education as they designed and developed interdisciplinary lessons integrating state math and science standards, engineering, and technology with robotics for grades first through fifth. All units developed included technology integration utilizing robotic devices. The pre-service candidates participated in a modified version of the Science Teaching Efficacy Beliefs Instrument (STEBI-B) survey during the semester and completed journal responses during classroom activities and after the teaching placement.

\subsection{Design of Study}

A mixed-methods approach to gather quantitative and qualitative data was used for this study. A mixed method approach can provide a more comprehensive picture of 
the data compared to a single design [43]. Quantitative measures were collected from a pre- and post-survey completed by the participants. Qualitative data was collected in the form of journal responses after preservice teachers participated in activities and teaching.

\subsection{Instruments}

The STEBI-B [44] modified by Bleicher [45] was used for the study. This instrument measures both of Bandura's constructs of efficacy: self-efficacy or individuals" "judgments of their capabilities to organize and execute courses of action required to attain designated types of performances" and outcome expectancy or individuals' judgments or beliefs regarding the contingency between a person's behavior and the anticipated outcome" [46]. To reflect a more general focus on STEM, items were rewritten to read "STEM" instead of "Science" in the survey. This modification was found to be reliable [47][48]. The survey consisted of 23 items on a five-point Likert scale with two subsets scales: The Personal STEM Teaching Efficacy (PSTE) and the STEM Teaching Outcome Expectancy (STOE) scales, which measures pre-service teachers beliefs about teaching STEM and elementary student outcomes as a result of STEM teaching. The instrument uses forward and reversed phrased items. Scores on the PSTE (13 items) can vary between 13 and 65 , and scores on the STOE (10 items) can range from 10 to 50. The STEBI-B was administered electronically. Pre-service teachers were given a unique code for participation in the study and to compare pre- and postdata. The qualitative data was also collected electronically. A unique code was also used for the journal and for comparison of quantitative and qualitative data. Reflections to journal questions were administered after the completion of the teaching experience. The journal questions included:

1. What past experience did you have with this type of planning?

2. What did the process look like designing the lessons?

3. What strategies did you use to influence your lessons?

4. What did you discover throughout the practicum?

5. Identify any new knowledge you will take from this practicum.

6. What influence do you perceive this having in your future classroom?

\subsection{Data Analysis}

A paired-samples t-test was conducted to compare pre- and post-survey data of participants self-efficacy and outcome expectancy, as measured by the STEBI-B. The journal entries were analyzed for themes for each of the six questions. Results of the journal responses were then compared to the quantitative data to identify trends that reflect changes in beliefs and outcomes in STEM teaching.

\section{Results}

\subsection{Quantitative}

A paired t-test was used to compare the pre- and post- STEBI-B survey. Analysis revealed significant increases between the means for both subscales, STOE and PSTE comparing the pre- and post-survey data. There was a significant difference in the mean score of pre-service $\mathrm{STOE}$ from pre-survey $(\mathrm{M}=35.9, \mathrm{SD}=4.5)$ to post-survey $(\mathrm{M}=37.9, \mathrm{SD}=4.6) ; \mathrm{t}(44)=-2.41,(\mathrm{p}=.020)$. The PSTE mean scores, were also significantly different for pre-survey $(\mathrm{M}=41.9, \mathrm{SD}=6.5)$ and post-survey $(\mathrm{M}=51.6, \mathrm{SD}=5.2) ; \mathrm{t}(44)=-9.9, \quad(\mathrm{p}=.000)$. The results suggest that pre-service teachers who participate in STEM-related activities and teaching increased their personal beliefs in STEM teaching and outcome expectancy of teaching STEM.

Table 1. t-test Paired Samples Results comparing STEBI-B subscales (STOE and PSTE)

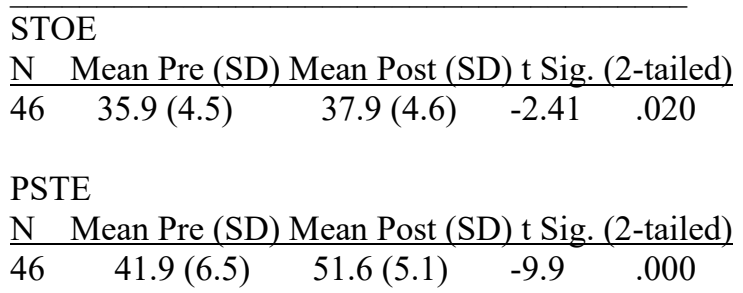

\subsection{Qualitative Data}

After the completion of the teaching experience, researchers analyzed the journal entries to compare with the quantitative data. The final journal questions and summary of responses are presented for each question.

Question 1: What past experience did you have with this type of planning? 
The majority of the pre-service teachers responded with having little to no experience at all with coding or robotics and writing integrated lessons with both science and math standards. Many commented that they had experience in writing lesson plans from other pedagogy courses but not in writing an entire unit. Others commented that this was the first experience where they were responsible to plan lesson plans with peers and teach the lessons.

Question 2: What did the process look like designing the lessons?

The process on how the pre-service teachers approached the lesson plan writing and unit plan was flexible. Around one-half of the pre-service teachers used the approach "divide and conquer" where each preservice teacher working in a grade level took one or two lesson plans and wrote them individually. These groups would still meet to collaborate using their time to offer feedback and suggestions. The other half of the preservice teachers working in other grade levels used the collaboration approach too; however, they used it to write all of the unit lessons together, as a group. Each group found value in the flexibility of being able to choose what worked for them and the ability to collaborate with their peers.

Question 3: What strategies did you use to influence your lessons?

One major theme pre-service teachers used in their reflections centered around classroom management techniques like modeling, collaboration, group discussions, engagement, and setting clear expectations. Other pre-service teachers focused on pedagogical skills like activating prior knowledge, problem-solving, handson learning, scaffolding and connecting the material to the real world and to elementary students' interests. One pre-service teacher commented, "Collaboration, modification, accommodations, peer and professional feedback, reflection, trial and error, ability groupings, small group work, modeling, experiential learning, challenges, autonomous behavior development in teamwork and in allowing elementary students to create their own rules/expectations in how to treat the robot and one another."

Question 4: What did you discover throughout the practicum?
The majority of the pre-service teachers responded with the "importance of reflection" and "being flexible" as one of the most important discoveries of this two-week practicum experience. The importance of being a reflective decision maker is a goal of the program. According to one pre-service teacher's journal entry, "I discovered there was always something I wanted to change after teaching a particular lesson. Once I saw the lesson in practice some of the parts of our lesson made sense and others did not seem to fit anymore."

Question 5: Identify any new knowledge you will take from this practicum.

A prominent theme stemming from this journal entry was "failure can lead to success" and focusing on "growth mindset." These two particular themes are taught during pedagogy courses but were strengthened during the practicum experience. Students responded: "I discovered that second graders are MORE than capable of overcoming challenges. These elementary students surprised me with their growth mindset, and how most groups would not give up until they figured it out. I discovered that these elementary students NEED to be challenged, not only mentally, but the emotional aspect was much more powerful for me to see." and "My definition of success changed because of this practicum. I used to believe that success was only when they complete the activity correctly but now I see it as elementary students learning something from the activity and giving their best effort to problem solve. Elementary students need to learn how to struggle, especially students who may not be challenged as much in school."

Question 6: What influence do you perceive this having in your future classroom?

Pre-service teachers frequently commented, "I will teach and incorporate STEM in my future classroom" multiple times in their journal responses and an increase in their confidence to teach combined standards, technology, and STEM concepts in their future classrooms. One student commented, "I think this will have a major impact on how I teach and reflect in my future classroom. This practicum gave me the courage to try new and exciting things with my elementary students and to have honest conversations with students about technology and being patient with new lessons or ideas." Another noted, "I think this will have a major impact on how I teach and reflect in my future classroom. This practicum gave me the courage to try new and exciting things with my elementary students and to have honest 
conversations with students about technology and being patient with new lessons or ideas." Yet another student stated, "I feel super prepared to use STEM in the classroom and feel comfortable using coding and robots.

\section{Discussion}

The primary goal of this study was to examine how pre-service teachers' perceptions of their effectiveness for teaching STEM change during a combined pedagogy course. Findings of this study provide valuable insight into an effective model for pre-service teachers to gain experience with STEM teaching using robotics. After a single semester, the pre-service teachers show significant positive changes in their self-efficacy and outcome expectancy with STEM teaching. The findings of this study are consistent with other research in content methods courses [49], [50], [51]. It was not surprising that pre-service teachers had not had experience with this type of planning or lesson implementation because this is not the overall design of our elementary program. Three themes directly related to our science and mathematics pedagogy combined courses were: STEM ideas, combining standards and increased comfort in working with technology. One student wrote, "I will do my best to combine standards to incorporate into a lesson as this STEM lesson did." In addition to math and science standards, many of the pre-service teachers integrated standards in literacy and social studies in these units. For example, to integrate literacy, the lesson required students to write a story and then coded the robot to act out a story. To integrate social studies standards, another lesson required students created a map and coded the robot to visit the locations on a map.

The findings of this study offer evidence that this type of planning with collaboration and feedback and a continuous teaching experience improves preservice teacher's confidence in their ability to teach STEM lessons. Many other themes related to pedagogical practices were identified through the analysis of journal writing, including the importance of such practices as guided instruction, modeling, being flexible, setting clear expectations, group work, and planning for diverse learners. The pre-service teachers' practical experience with classroom management, management of technology, and flexibility with learning groups may be attributed to the fact that several elementary students in the practicum classrooms received accommodations for special education services or services related to language learners. One pre-service teacher noted, "I will take this experience for its value in providing accommodations, chunking, pacing, and care for elementary students struggling with social, academic, and developmental areas. I will also take the belief that students are capable of rising to the challenge when they are adequately supported and engaged."

For teacher educators to successfully teach STEM that integrates robotics, it is essential to include time for preservice teachers to collaborate with peers as well as the actual implementation of the lessons with K-12 students. Although this research did not measure elementary students' learning during this research, the pre-service teachers did feel confident in the learning and engagement demonstrated by the elementary students during the STEM units. Many noted not only the growth in knowledge of the elementary students but also improved the ability to problem-solving and collaborate within the classes they taught.

\subsection{Limitations}

Several limitations were present in this study. First, the generalization of this study is limited due to the small number of participants. Two semesters of data was combined to increase the number of data points for the study. Each year, between 40-60 pre-service teachers are enrolled over two semesters in these courses. However, even with the relatively small sample size, the model for STEM integration with the combined courses does help address the need to prepare qualified STEM educators. Second, a variety of robotic devices based on the grade level were used. Some robots were easier to integrate math and science lessons based on the capability of the robot. Success or failure sometimes was impacted by the limitations of the available technology. Lastly, host teachers' experiences with STEM may or may not have had an impact on the pre-service teacher's experiences in the classroom. It is difficult to find school placements where the backgrounds and motivations of the in-service teachers match the goals of the program.

\subsection{Future Recommendations}

The initial results of this study have promising implications for increasing the confidence of preservice teachers in their ability to teach STEM. Many of the preservice teachers who participated in this study implemented similar STEM lessons during their final semester of student teaching experience. A pressing question that warrants further study is how this approach to teacher preparation impacts preservice teachers' teaching practices when they begin their career. A similar study done with secondary educators recommended that in-service teachers who are committed to STEM 
integration would be used to collaborate with pre-service teachers and programs. Practicing teachers could participate in professional development and serve as STEM integration experts. This would further facilitate the development of a community of integrated STEM teachers [52]. An additional recommendation for future research in the area of STEM integration would be to capture the impact on elementary students, and determining whether the interdisciplinary approach of addressing content standards with robotics has an impact on the motivation students to explore STEM careers.

\section{References}

[1] Lynch, S. J., Peters-Burton, E. \& Ford, M. (2014). Building STEM opportunities for all. Education Leadership, 72(4), 5460.

[2] Ryu, M., Mentzer N., \& Knobloch, N. (2019). Pre-service teachers' experiences of STEM integration: challenges and implications for integrated STEM teacher preparation. International Journal of Technology \& Design Education, 29(3), 493-512. https://doi-org.ezproxy.csbsju.edu/10.1007/s1 0798-018-9440-9

[3] Wang, H., Moore, T. J., Roehrig, G. H., \& Park, M. S. (2011). STEM integration: Teacher perceptions and practice. Journal of Pre-College Engineering Education Research, 1(2), Article 2.

[4] Nadelson, L. S., Seifert, A., Moll, A. J., \& Coats, B. (2012). i-STEM summer institute: An integrated approach to teacher professional development in STEM. Journal of STEM Education: Innovations and Research, 13(2), 69.

[5] Roehrig, G. H., Wang, H.-H., Moore, T. J., \& Park, M. S. (2012). Is adding the E enough? Investigating the impact of K12 engineering standards on the implementation of STEM integration. School Science and Mathematics, 112(1), 31-44.

[6] Berlin, D. F., \& White, A. L. (2012). “A longitudinal look at attitudes and perceptions related to the integration of mathematics, science, and technology education." School Science and Mathematics, 112(1), 20-30.

[7] Honey, M., Pearson, G., \& Schweingruber, H. (2014). "STEM integration in K-12 education: Status, prospects, and an agenda for research. Committee on Integrated STEM Education; National Academy of Engineering; National Research Council. Washington, DC: The National Academies Press.

[8] Ortiz, A., Bos, B., \& Smith, S. (2015). "The Power of Educational Robotics as an Integrated STEM Learning Experience in Teacher Preparation Programs." Journal of
College Science Teaching, 44(5), 42-47. Retrieved from http://www.jstor.org/stable/43631847

[9] Nadelson, L. S., Seifert, A., Moll, A. J., \& Coats, B. (2012). i-STEM summer institute: An integrated approach to teacher professional development in STEM. Journal of STEM Education: Innovations and Research, 13(2), 69.

[10] Bandura, A. (1977). Self-efficacy: Toward a unifying theory of behavioral change. Psychological Review, 84, 191215 .

[11] Bandura, A. (1982). Self-efficacy mechanism in human agency. American Psychologist, 37, 122-147

[12] Bandura, A. (1989). Human agency in social cognitive theory. American Psychologist, 44, 1175-1184.

[13] Zimmerman, B. J., Bandura, A., \& Martinez-Pons, M. (1992). Self-motivation for academic attainment: The role of self-efficacy beliefs and personal goal-setting. American Educational Research Journal, 29, 663-676.

[14] Bursal, M., \& Paznokas, L. (2006). Mathematics anxiety and pre-service elementary teachers' confidence to teach mathematics and science. School Science and Mathematics, 106(4), 173-179.

[15] National Research Council. (2007). Taking Science to School: Learning and Teaching Science in Grades K-8. Committee on Science Learning, Kindergarten Through Eighth Grade. R. A. Duschl, H. A. Schweingruber, and A. W. Shouse, Editors. Board on Science Education, Center for Education. Division of Behavioral and Social Sciences and Education. Washington, wDC: The National Academies Press.

[16] Beilock, S. L., Gunderson, E. A., Ramirez, G., \& Levine, S. C. (2010). Female teachers' math anxiety affects girls' math achievement. Proceedings of the National Academies of Science, 107, 1860-1863.

[17] Ryu, M., Mentzer N., \& Knobloch, N. (2019). Pre-service teachers' experiences of STEM integration: challenges and implications for integrated STEM teacher preparation. International Journal of Technology \& Design Education, 29(3), 493-512. https://doi-org.ezproxy.csbsju.edu/10.1007/s1 0798-018-9440-9

[18] Menon, D., \& Sadler, T. D. (2016). Pre-service elementary teachers' science self-efficacy beliefs and science content knowledge. Journal of Science Teacher Education, 27(6), 649673.

[19] Coburn, W. W., \& Loving, C. C. (2002). Investigations of preservice elementary teachers' thinking about science. Journal of Research in Science Teaching, 39, 1016-1031. 
[20] Archer, L., DeWitt, J., Osborne, J., Dillon, J., Willis, B., \& Wong, B. (2013). "Not girly, not sexy, not glamorous": primary school girls' and parents' constructions of science aspirations. Pedagogy, Culture \& Society, 21(1), 171e194. http://doi.org/10. 1080/14681366.2012.748676.

[21] Hossain, M. \& Robison, M.G. (2012). How to motivate US students to pursue STEM (science, technology, engineering and mathematics) careers. Online Submission. US-China Education Review (2012) 442-451.

[22] Maltese, A. V. Tai, R. H. (2010) Eyeballs in the Fridge: Sources of early interest in science, International Journal of Science Education, 32 (5), 669-685, DOI: $10.1080 / 09500690902792385$

[23] DeJarnette, N. K. (2012). America's children: Providing early exposure to STEM (science, technology, engineering, and math) initiatives. Education, 133(1), 77-84.

[24] Corlu, M. S., Capraro, R. M., \& Capraro, M. M. (2014). Introducing STEM education: Implications for educating our teachers in the age of innovation. Education and Science,39(171), 74-85

[25] Stubbs, E. A., \& Myers, B. E. (2016). Part of what we do: Teacher perceptions of STEM integration. Journal of Agricultural Education, 57(3), 87-100.

[26] Murphy, T. P., \& Mancini.-Samuelson, G. J. (2012). Graduating STEM Competent and Confident Teachers: The Creation of a STEM Certificate for Elementary Education Majors. Journal of College Science Teaching, 42(2), 18-23. Retrieved from http://search.ebscohost.com.ezproxy.csbsju.edu $/$ login. aspx?direct $=$ true $\& d b=a p h \& A N=82689661 \&$ site $=$ ehostlive \&scope $=$ site

[27] Adams, A. E., Miller, B. G., Saul, M., \& Pegg, J. (2014). Supporting elementary pre-service teachers to teach STEM through place-based teaching and learning experiences. Electronic Journal of Science Education, 18(5), 1-22.

[28] O'Brien, S. (2010, June). A unique multidisciplinary STEM K-5 teacher preparation program. American Society for Engineering Education Annual Conference \& Exposition, Louisville, Kentucky. https://peer.asee.org/16301

[29] Mativo, J.M. \& Park, J.H. (2012). Innovative and creative K-12 engineering strategies. Implications of pre-service teachers survey. Journal of STEM Education, 13(5) 26-29.

[30] Berlin, D. F., \& White, A. L. (2012). “A longitudinal look at attitudes and perceptions related to the integration of mathematics, science, and technology education." School Science and Mathematics, 112(1), 20-30.
[31] Wang, H., Moore, T. J., Roehrig, G. H., \& Park, M. S. (2011). "STEM integration: Teacher perceptions and practice." Journal of Pre-College Engineering Education Research, 1(2), Article 2.

[32] Kaya, E., Newley, A. Deniz, H., Yesilyurt, \& Newly, P. (2017). Introducing engineering design to a science teaching methods course through educational robotics and exploring changes in views of pre-service elementary teachers. Journal of College Science Teaching 47(2), 66-75

[33]Barker, B. S., \& Ansorge, J. (2007). Robotics as means to increase achievement scores in an informal learning environment. Journal of Research on Technology Education, 39, 229-243.

[34] Mataric, M. J., Koenig, N. P., \& Feil-Seifer, D. (2007, March). Materials for Enabling Hands-On Robotics and STEM Education. In AAAI spring symposium: Semantic scientific knowledge integration (pp. 99-102).

[35] Nelson, C. A. (2012). Generating transferable skills in STEM through educational robotics. In B. S. Barker, G. Nugent, N. Grandgenett, \& V. I. Adamchuk(Eds.), Robots in K-12 education: A new technology for learning (pp. 54-65). Hershey, PA: IGI Global.

[36] Arlegui, J., Pina, A., \& Moro, M. (2013, November). A PBL approach using virtual and real robots (with BYOB and LEGO NXT) to teaching learning key competences and standard curricula in primary level. In Proceedings of the First International Conference on Technological Ecosystem for Enhancing Multiculturality. New York, NY, USA: ACM. http://doi.org/10.1145/2536536.2536585.

[37] Sullivan, A., \& Bers, M. U. (2016). Robotics in the early childhood classroom: learning outcomes from an 8-week robotics curriculum in pre-kindergarten through second grade. International Journal of Technology and Design Education, 26(1), 3-20.

[38] Pierson, M., \& Thompson, M. (2005). The re-envisioned educational technology course: If addition isn't possible, try division. Journal of Computing in Teacher Education, 22(1), 31-36.

[39] Shapley, K. S., Benner, A. D., Pieper, A. M., Way, P. J., Snider, S. L., \& Gershner, V. T. (2003, April). Integrating technology into teacher education: Navigating the complexity of institutional change. Paper presented at the American Educational Research Association.

[40] Tondeur, J., van Braak, J., Sang, G., Voogt, J., Fisser, P., \& Ottenbreit-Leftwich, A. (2012). Preparing pre-service teachers to integrate technology in education: A synthesis of qualitative evidence. Computers \& Education,59(1), 
[41] Kay, J. S., Moss, J. G., Engelman, S., \& McKlin, T. (2014, March). Sneaking in through the back door: introducing K-12 teachers to robot programming. In Proceedings of the 45th $\mathrm{ACM}$ technical symposium on Computer science education(pp. 499-504). ACM.

[42] Kim, C., Kim, D., Yuan, J., Hill, R. B., Doshi, P., \& Thai, C. N. (2015). Robotics to promote elementary education preservice teachers' STEM engagement, learning, and teaching. Computers \& Education, 91, 14-31. https://doi-org.ezproxy.csb sju.edu/10.1016/j.compedu.2015.08.005

[43] Morse, J. M., \& Niehaus, L. (2009). Mixed method design: Principles and procedures. Walnut Creek, CA: Left Coast Pr.

[44] Enochs, L. G. \& Riggs. I. M. (1990). Further development of an elementary science efficacy belief instrument: A preservice elementary scale. School Science and Mathematics, 90, 694-706.

[45] Bleicher, R.E. (2004). Revisiting the STEBI-B: Measuring self-efficacy in pre-service elementary teachers. School of Science and Mathematics, 104, 383-391.

[46] Bandura, A. (1986). Social foundations of thought and action: A social cognitive theory. Englewood Cliffs, NJ: Prentice-Hall

[47] Nadelson, L.S., Callahan, J., Pyke, P., Hay, A. \& Schrader, C. (2010, June). Teaching Inquiry-Based STEM in the Elementary Grades Using Manipulatives: A SySTEMic Solution Report. American Society for Engineering Education Annual Conference \& Exposition, Louisville, Kentucky. https://peer.asee.org/16395

[48] Nadelson, L. S., Seifert, A., Moll, A. J., \& Coats, B. (2012). i-STEM summer institute: An integrated approach to teacher professional development in STEM. Journal of STEM Education: Innovations and Research, 13(2), 69.

[49] Bautista, N. U. (2011). Investigating the use of vicarious and mastery experiences in influencing early childhood education majors' self-efficacy beliefs. Journal of Science Teacher Education, 22, 333-349.

[50] Menon, D., \& Sadler, T. D. (2016). Pre-service elementary teachers' science self-efficacy beliefs and science content knowledge. Journal of Science Teacher Education, 27(6), 649673.

[51] Murphy, T. P., \& Mancini.-Samuelson, G. J. (2012). Graduating STEM Competent and Confident Teachers: The Creation of a STEM Certificate for Elementary Education Majors. Journal of College Science Teaching, 42(2), 18-23. Retrieved from http://search.ebscohost.com.ezproxy.csbsju.edu $/$ login.aspx direct $=$ true $\& d b=$ aph \&AN=82689661\& site $=$ ehostlive \&scope $=$ site
[52] Ryu, M., Mentzer N., \& Knobloch, N. (2019). "Pre-service teachers' experiences of STEM integration: challenges and implications for integrated STEM teacher preparation." International Journal of Technology \& Design Education, 29(3), pp. 493-512. https://doi-org.ezproxy.csbsju.edu/10.1007 /s10798-018-9440-9 